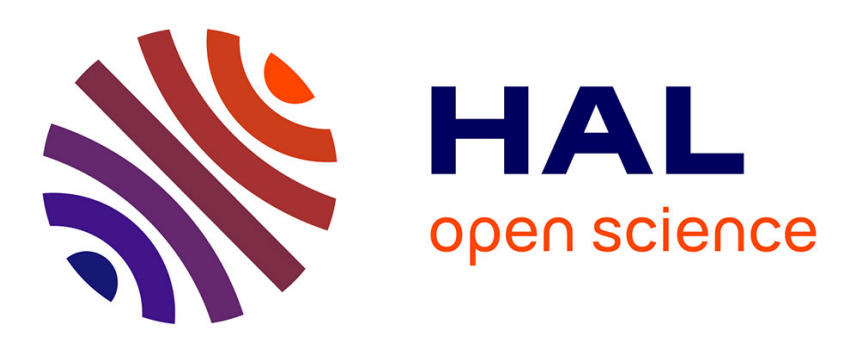

\title{
Negative cerium anomalies in manganese (hydr)oxide precipitates due to cerium oxidation in the presence of dissolved siderophores
}

Dennis Kraemer, Nathalie Tepe, Olivier Pourret, Michael Bau

\section{- To cite this version:}

Dennis Kraemer, Nathalie Tepe, Olivier Pourret, Michael Bau. Negative cerium anomalies in manganese (hydr)oxide precipitates due to cerium oxidation in the presence of dissolved siderophores. Geochimica et Cosmochimica Acta, 2017, 196, pp.197-208. 10.1016/j.gca.2016.09.018 . hal-02265545

\author{
HAL Id: hal-02265545 \\ https://hal.science/hal-02265545
}

Submitted on 10 Aug 2019

HAL is a multi-disciplinary open access archive for the deposit and dissemination of scientific research documents, whether they are published or not. The documents may come from teaching and research institutions in France or abroad, or from public or private research centers.
L'archive ouverte pluridisciplinaire HAL, est destinée au dépôt et à la diffusion de documents scientifiques de niveau recherche, publiés ou non, émanant des établissements d'enseignement et de recherche français ou étrangers, des laboratoires publics ou privés. 
Negative cerium anomalies in manganese (hydr)oxide precipitates due to cerium oxidation in the presence of dissolved siderophores

\author{
Dennis Kraemer ${ }^{1^{\star}}$, Nathalie Tepe ${ }^{1,2}$, Olivier Pourret ${ }^{3}$ and Michael Bau ${ }^{1}$ \\ ${ }^{1}$ Department of Physics and Earth Sciences, Jacobs University Bremen, Campus Ring 1, \\ 28759 Bremen, Germany \\ 2 present address: University of Vienna, Department of Environmental Geosciences, \\ Althanstrasse 14, 1090 Vienna, Austria \\ ${ }^{3}$ HydrISE, Institut Polytechnique LaSalle Beauvais, 60026 Beauvais cedex, France \\ *email: d.kraemer@jacobs-university.de
}

\title{
Abstract
}

We present experimental results on the sorption behavior of rare earth elements and yttrium (REY) on precipitating manganese (hydr)oxide in the presence of the biogenic siderophore desferrioxamine B (DFOB). In marked contrast to inorganic systems, where preferential adsorption of HREY and depletion of LREY is commonly observed in manganese (hydr)oxide precipitates, sorption of REY in presence of the DFOB siderophore leads to HREY-depleted and LREY-enriched patterns in the precipitates. Moreover, our data indicate that surface oxidation of $\mathrm{Ce}$ (III) to $\mathrm{Ce}$ (IV) during sorption onto manganese (hydr)oxides and the resulting development of a positive Ce anomaly, which are commonly observed in inorganic experiments, are prevented in the presence of DFOB. Instead, $\mathrm{Ce}(\mathrm{III})$ is oxidized to $\mathrm{Ce}(\mathrm{IV})$ but associated with the dissolved desferrioxamine $\mathrm{B}$ which forms complexes with $\mathrm{Ce}(\mathrm{IV})$, that are at least twenty orders of magnitude more stable than those with $\mathrm{Ce}(\mathrm{III})$ and $\mathrm{REY}(\mathrm{III})$. The overall result is the formation of a positive $\mathrm{Ce}$ anomaly in the solution and a negative $\mathrm{Ce}$ anomaly in the $\mathrm{Mn}$ (hydr)oxides. The distribution of the strictly trivalent REY and Eu(III) between the manganese (hydr)oxide phase and the remaining ambient solution mimics the distribution of published stability constants for complexes of REY(III) with DFOB, i.e. the heavy REY form more stable complexes with the ligand and hence are better shielded from sorption than the LREY. Surface complexation modeling corroborates our experimental results. Negative $\mathrm{Ce}$ anomalies in Mn precipitates have been described from biogenic Mn oxides. Our results provide experimental evidence for the development of negative $\mathrm{Ce}$ anomalies in abiogenic $\mathrm{Mn}$ (hydr)oxide precipitates and show that the presence of the widespread siderophore desferrioxamine B during mineral precipitation results in HREY-depleted Mn (hydr)oxides with negative $\mathrm{Ce}$ anomalies.

\section{Introduction}


The rare earth elements (REE+Y; REY) are a group of chemically coherent elements and consist of the lanthanides La, Ce, Pr, Nd, Pm, Sm Eu, Gd, Tb, Dy, Ho, Er, Tm, Yb, Lu and the pseudolanthanoid $Y$. The lanthanides are further subdivided into the light REY (LREY; La-Gd) and heavy REY (HREY; Tb-Lu+Y). Rare earth elements are increasingly used in many high-technological applications (Humphries, 2013). Apart from a significantly rising demand and thus a greater need for viable economic deposits and more effective metallurgical (heavy) REY extraction techniques, the extensive use of REY in technological, medicinal and agricultural applications comes along with a significantly enhanced anthropogenic input into the environment. Thus, understanding the fate of REY in the supergene realm is of importance for addressing health-related and environmental issues. The REY are also widely used as geochemical proxies for reconstructing the physico-chemical conditions in aqueous and magmatic systems.

In natural systems, the REY are, with the exceptions of $\mathrm{Ce}$ and $\mathrm{Eu}$, strictly trivalent and hence show similar behavior for the whole lanthanide series depending on their specific charge and ionic radii. Cerium and Eu are redox-sensitive and may occur in natural systems also as reduced $\left(\mathrm{Eu}^{2+}\right)$ or oxidized species $\left(\mathrm{Ce}^{4+}\right)$. In the latter case, the higher charge and smaller ionic radius of $\mathrm{Ce}^{3+}$ compared to $\mathrm{Ce}^{4+}$ leads to decoupling of Ce from its strictly trivalent REY neighbors. Cerium(IV) is usually less mobile than REY(III), which may result in the formation of Ce anomalies during partitioning of REY between solutions and solids. While anomalous behavior of $\mathrm{Ce}$ is often observed in lowtemperature aquatic systems, the development of Eu anomalies is confined to hightemperature reducing systems. Lanthanide tetrad effects have been described in lowtemperature aquatic environments (Masuda et al., 1987; Masuda and Akagi, 1989; Bau, 1996, 1999; Minami et al., 1998; Bau et al., 1998; Ohta and Kawabe, 2001; Pourret et al., 2008; Bau and Koschinsky, 2009; Tanaka et al., 2010). Yttrium anomalies or fractionation of $Y$ and $H o$ are common and typical of aqueous systems and highly evolved magmatic systems (Bau, 1996).

In natural systems, metal (hydr)oxides are very efficient scavengers of particlereactive elements like the REY and, thus, the removal of REY from seawater by metal (hydr)oxides, for example, is an important geochemical process (e.g., Koeppenkastrop and De Carlo, 1992; Ohta and Kawabe, 2001; Bau and Koschinsky, 2009; Mayanna et al., 2015). The speciation of REY(III) in seawater is dominated by carbonate complexes (Millero, 1992; Schijf et al., 2015). The competition of dissolved carbonate ligands with hydroxyl and/or organic functional groups located on the surface of the metal(hydr)oxides leads to constant sorption and desorption of trivalent REY at the particle surfaces (Bau and Koschinsky, 2009) even after an exchange equilibrium has been reached. The redox-sensitive lanthanoid $\mathrm{Ce}$ is significantly depleted relative to its trivalent LREY neighbors. This fractionation of Ce from its strictly trivalent LREY neighbors is caused by oxidative scavenging of $\mathrm{Ce}^{3+}$ as $\mathrm{Ce}^{4+}$ during sorption onto $\mathrm{Mn}$ and $\mathrm{Fe}$ (hydr)oxide compounds in the water column (e.g., Bau and Koschinsky, 2009). Oxidative scavenging occurs in three independent steps: (i) initial sorption of $\mathrm{Ce}$ (III) from seawater 
along with the other REY(III), (ii) partial oxidation of $\mathrm{Ce}$ (III) to $\mathrm{Ce}(\mathrm{IV})$ on the (hydr)oxide surface, and (iii) limited desorption of Ce(IV) relative to the REY(III) (e.g., Bau, 1999; Bau and Koschinsky, 2009). This oxidative process enriches $\mathrm{Ce}(\mathrm{IV})$ on the particle surfaces and may result in the formation of positive Ce anomalies in normalized REY patterns. Manganese and $\mathrm{Fe}$ (hydr)oxide particles continuously scavenge particle-reactive trace metals and slowly accumulate $\mathrm{Ce}$ from the ambient solution. They may, therefore, develop positive Ce anomalies, whereas the ambient solution (e.g., seawater) is depleted in Ce and may show a negative $\mathrm{Ce}$ anomaly. Absence and presence of $\mathrm{Ce}$ anomalies are widely used in geochemistry and (paleo-)oceanography as proxies for redox conditions (i.e., German and Elderfield, 1990; Bau and Dulski, 1996; Pattan et al., 2005; Bau and Alexander, 2006; 2009; Frei et al., 2009; Baldwin et al., 2012; Frei et al., 2013), provided that post-depositional processes did not alter the pristine REY signal.

Experimental evidence for preferential sorption and the development of specific REE signatures is given by, amongst others, Bau (1999) for Fe oxyhydroxides and Ohta and Kawabe (2001) for $\mathrm{Mn}$ dioxide and $\mathrm{Fe}$ oxyhydroxide, respectively. $\mathrm{Ce}$ is oxidatively scavenged by metal (hydr)oxides, but $\mathrm{MnO}_{2}$ exhibits a stronger oxidizing potential for $\mathrm{Ce}^{3+}$ than $\mathrm{Fe}$ (hydr)oxides due to $\mathrm{Mn}$ acting as a catalyst for Ce oxidation (Ohta and Kawabe, 2001). Their sorption experiments revealed that $\mathrm{REE}$ sorption onto $\mathrm{MnO}_{2}$ leads to the formation of positive $\mathrm{Ce}$ anomalies in the oxides even at slightly acidic to circumneutral $\mathrm{pH}$.

The behavior of cerium during particle scavenging was described in a range of scientific publications (e.g., Koeppenkastrop and De Carlo, 1992; Carlo and Wen, 1998; Davranche et al., 2004; Quinn et al., 2006b; Quinn et al., 2006a; Quinn et al., 2007; Davranche et al., 2008; Schijf and Marshall, 2011). However, the presence of organic ligands or organic-ligand producing biota may drastically affect REY fractionation during scavenging onto mineral particles. For example, Figure 1 shows the REY partition coefficients between $\mathrm{MnO}_{2}$ and ambient solution as obtained by Ohta and Kawabe (2001) for inorganic REY sorption and by Davranche et al. (2005) for REY sorption in presence of humate ligands. Davranche and coworkers $(2004,2005)$ conducted REE (not considering $Y$ ) sorption experiments with $\mathrm{Fe}$ oxyhydroxide (Davranche et al., 2004) and $\mathrm{MnO}_{2}$ (Davranche et al., 2005) and showed that for both experimental approaches, the complexation of REE with humate ligands effectively prevents the development of $\mathrm{Ce}$ anomalies during REE partitioning between ambient solution and the precipitates. The authors argued that REE are predominantly bound as humate complexes, which prevents sorption to particles or which adsorb to particles as a ternary complex and hence shield $\mathrm{Ce}$ from the oxidizer, in this case $\mathrm{MnO}_{2}$. Humate complexation hence prevents the fractionation of redox-sensitive cerium from its strictly trivalent REY neighbors during scavenging by oxide particles. Tanaka et al. (2010; Fig. 1) conducted an experimental study on the sorption behavior of REE on biogenic Mn oxides in the presence of organicligand producing bacteria and showed that $\mathrm{Ce}$ is preferentially oxidized and negative $\mathrm{Ce}$ anomalies develop during the biogenic formation of Mn dioxide. Ohnuki et al. (2015) 
elucidated the role of microorganisms on $\mathrm{Ce}$ (III) oxidation during $\mathrm{Ce}$ sorption onto synthetic Mn oxides in presence of cells of Pseudomonas fluorescens. They showed that $\mathrm{Ce}$ (III) oxidation is correlated to the amount of microbial cells present during sorption and that less $\mathrm{Ce}(\mathrm{III})$ is oxidized in experiments with higher abundance of microbial cells. They conclude that $\mathrm{Ce}(\mathrm{III})$ is associated with microbial cell surfaces and forms Ce phosphate nanoparticles, which are responsible for suppressing the oxidation of $\mathrm{Ce}$ (III) during sorption. In summary, Fe and Mn (hydr)oxides efficiently sorb REY. In inorganic solutions, i.e., in absence of microbes and of organic ligands, $\mathrm{Ce}$ is oxidatively scavenged and this process leaves a Ce-depleted residual solution. However, in presence of microbes and/or organic compounds, both absence of $\mathrm{Ce}$ anomalies and negative $\mathrm{Ce}$ anomalies in the solid phases, or Ce-enriched residual solutions, have been described.

We conducted sorption experiments with REY on precipitating Mn (hydr)oxides in the presence of the biogenic compound desferrioxamine B (DFOB). This compound belongs to a group of metal-specific organic ligands commonly referred to as siderophores or metallophores (Kraemer et al., 2014, and references therein). These ligands are lowmolecular weight organic molecules synthesized by bacteria and plants in oxidized environments to cope with iron deficiency. In oxidized systems, $\mathrm{Fe}$ is trivalent and thus is immediately fixed in insoluble oxyhydroxide structures and hence removed from the bioavailable dissolved pool. Therefore, under modern atmospheric conditions, the essential nutrient $\mathrm{Fe}$ is not available to organisms, and siderophores are excreted by plants, microbes and fungi to facilitate the dissolution of Fe-bearing oxide and oxyhydroxide minerals (Neilands, 1957; Haas, 2003; Kraemer et al., 2014). However, it was recently shown that siderophores not only form highly stable complexes with $\mathrm{Fe}(\mathrm{III})$, but that they also significantly complex other polyvalent metal ions, some of which are considered toxic at higher concentrations, but are essential nutrients at trace concentrations (e.g., Kraemer et al., 2014). Several studies showed that siderophore chelation of heavy metals reduces metal uptake by bacteria, fungi and plants and siderophores thus play a vital role in heavy metal detoxification (Höfte et al., 1993; Teitzel et al., 2006; Braud et al., 2010; O'Brien et al., 2014).

Christenson and Schijf (2011) determined the complex stability constants for REY at seawater ionic strength with the siderophore DFOB. Figure 2 shows the stability constants for hexadentate $\left(\log \beta_{3}\right)$ complexes and compares them to those of mono- and dicarbonate complexes which are the dominating complex species for REY in many natural systems such as seawater. As a comparison, figure 2 also shows equilibrium constants for REY binding on the surface of the gram positive Bacillus subtilis bacteria (Martinez et al., 2014). It can be seen that DFOB stability constants with REY(III) are several orders of magnitude higher than those for mono- and dicarbonate complexes and that complex stabilities increase with decreasing ionic radii. Also note that $\mathrm{Y}$ (III)-DFOB complexes are only slightly weaker than $\mathrm{Ho}$ (III)-DFOB complexes. Similar trends, but less extreme, are observed in the Bacillus subtilis dataset (Martinez et al., 2014). Noteworthy is the similar preference for HREY(III) for both DFOB and the bacteria, similar to the 
experimental results on bacterial dissolution of hornblende minerals (Brantley et al., 2001). A study by Bau et al. (2013) demonstrated that REE are significantly leached from the particulate pool of glacial-fed river water from Iceland when the samples are incubated with the DFOB siderophore and that the presence of DFOB increases the dissolved concentrations of REE by several orders of magnitude. Furthermore, positive Ce anomalies were found in the dissolved pool after incubation with DFOB, indicating oxidative solubilization and preferential mobilization of tetravalent Ce over trivalent REE from volcanic ash particles to solution. Kraemer et al. (2015) showed that leaching of igneous rocks in presence of DFOB enhances the mobility of 'immobile' trace elements like $\mathrm{REY}, \mathrm{Zr}, \mathrm{Hf}$, Th and $\mathrm{U}$ and that, regardless of the chemical and mineralogical composition of the leached rock, concave downward LREY patterns, a depletion of LREY over HREY, and positive Ce anomalies develop in the leachates containing siderophores.

In this study, we conducted experiments similar to the ones presented by Bau (1999), Ohta and Kawabe (2001) and Davranche et al. (2005). However, instead of sorbing from strictly inorganic solutions (Bau, 1999; Ohta and Kawabe, 2001) or from humic acidbearing solutions (Davranche et al., 2005), REY sorption experiments were conducted in the presence of the DFOB siderophore to elucidate the role of this abundant biogenic compound on REY fractionation during experimental sorption of REY onto Mn (hydr)oxides.

\section{Methods}

\subsection{Experimental}

The experimental approach used in this study was modified after Bau (1999). Instead of $\mathrm{Fe}, \mathrm{Mn}$ is precipitated as (hydr)oxide during the scavenging experiments by increasing the $\mathrm{pH}$ of a Mn-REY-DFOB solution and REY are sorbed during precipitate formation. There is no mineralogical data available for the precipitating Mn (hydr)oxides and the surface properties and mineral characteristics are not known. All experiments were conducted as time-series experiments with time intervals of $6.5,15,30,60,120$ and 240 $\min$.

All reagents used for the experimental setup were of suprapure grade and lab work was done with acid-cleaned lab-equipment and in a trace-metal clean environment. De-ionized water used in this study for preparation of the artificial solution was purified by reverse osmosis and ion exchange in a MilliQ Millipore purification system to an electric conductivity of $18 \mathrm{M} \Omega{ }^{*} \mathrm{~cm}$. Element standards by InorganicVentures Inc. were used to prepare the REY stock solutions needed for the experiments. The exact composition of the artificial REY solution used for the sorption experiments is given in Table 1.

The model siderophore used for this study is the hydroxamate compound desferrioxamine B or in short DFOB. Desferrioxamine B is one of the most thoroughly studied siderophores and occurs in many environments with concentrations from the nanomolar up to the millimolar range (Römheld, 1991; Kraemer, 2004). The mesylate salt 
of DFOB used in this study is sold as a drug for treatment of chronic iron overload under the trademark Desferal ${ }^{T M}$. Christenson and Schijf (2011) reported that mesylate-REE stability constants are negligible compared to the high DFOB-REE constants and hence there should be no significant interference by REE complexation with mesylate ions. Purities of all reagents were cross-checked by blank measurements with ICP-MS and were found to be at least two orders of magnitude below element concentrations presented in this study.

The artificial solution used in the sorption experiments is composed of $\Sigma \mathrm{REY}=0.407 \mu \mathrm{mol} / \mathrm{L}$ (see table 1) in $0.01 \mathrm{~mol} / \mathrm{L} \mathrm{HCl}$. Lanthanide complexation in the ICP standards is dominated by REY-nitrate complexes. However, because the stability of REE-nitrate complexes is negligible (log $K_{f}<<1$, Millero, 1992) compared to that of REYDFOB complexes, they do not influence the results of this study. Exactly $50 \mathrm{ml}$ of the REY solution was transferred to an acid-cleaned low-density polyethylene (LDPE) bottle. The $\mathrm{pH}$ of the solution was set with $1 \mathrm{~mol} / \mathrm{L} \mathrm{NaOH}$ (suprapure) until a $\mathrm{pH}$ of 4 to 5 is reached before DFOB was added to the solution in amounts matching a final DFOB molarity of exactly $100 \mu \mathrm{mol} / \mathrm{L}$ in solution. Manganese was pipetted from a $182 \mathrm{mmol} / \mathrm{L}$ (10.000 ppm) single element standard by InorganicVentures $/ n c$. to match $0.182 \mathrm{mmol} / \mathrm{L}$ $\mathrm{Mn}$, present as $\mathrm{Mn}^{2+}$, in the final $50 \mathrm{ml}$ REY-DFOB solution. After an equilibration phase of ca. $30 \mathrm{sec}$, the $\mathrm{pH}$ was set to about 9 by addition of $33 \mu \mathrm{l} 1 \mathrm{~mol} / \mathrm{L}$ suprapure $\mathrm{NaOH}$ to provoke precipitation of Mn (hydr-)oxides and the LDPE bottle was closed and placed on a horizontal shaker table and shaken at $180 \mathrm{rpm}$. The time intervals chosen for the sorption experiments were 6.5, 15, 30, 60, 120 and $240 \mathrm{~min}$. For each incubation time step, a separate LDPE bottle was used. All sorption experiments were run as duplicates for quality control and reproducibility of the experimental results. After incubation, each LDPE bottle was taken from the shaker table and the solution was immediately filtered with a Sartorius filter tower with a $0.2 \mu \mathrm{m}$ membrane filter to separate the manganese precipitates from the residual solution. Before filtration, the $\mathrm{pH}$ was measured. Due to precipitation of $\mathrm{Mn}$ (hydr-)oxides and the formation of $\mathrm{H}^{+}$-ions, the $\mathrm{pH}$ of the solution dropped to $\mathrm{pH}$ values $<7.5$ in the first $15 \mathrm{~min}$ of the sorption experiments, and then stabilized at close to 7.5 . The filtered leachate was acidified with $1 \mathrm{~mL}$ of suprapure $30 \%$ $\mathrm{HCl}$. The Mn (hydr)oxides were digested together with the membrane filters with a mixture of $\mathrm{HF} / \mathrm{HNO}_{3} / \mathrm{HCl}$ in a Picotrace DAS digestion unit at elevated pressure and temperatures. The filtrates and the digested filter residues were analyzed with an inductively coupled plasma-mass spectrometer (ICP-MS; see below). The concentrations in the filtrates and the digested filter residues were normalized to the original dilution factors and sampling-induced volume variations were considered. Recovery rates $\left(R E Y_{\text {filtrate }}+R E Y_{\text {filter }} / R E Y_{\text {stock }}{ }^{*} 100\right)$ for the whole $R E Y$ series were in the range of $80 \%$ to $100 \%$ with the LREY showing lower recovery rates than the heavier REY. Recovery rates tended to decrease with increasing incubation times, which may be due to adsorption of REY on LDPE bottle walls due to the near-neutral $\mathrm{pH}$ of the experimental solutions. The 
trends observed in recovery rates during the experiments have no effect on the fractionation patterns presented in this study.

\subsection{Analytical and Reporting}

All filtrates as well as the corresponding dissolved filter residues from the sorption experiments were measured for REY concentrations with a Perkin-Elmer low-resolution quadrupole ICP-MS Elan 6000 DRC-e. $1 \mu \mathrm{g} / \mathrm{l}$ of each $\mathrm{Ru}, \mathrm{Re}$ and $\mathrm{Bi}$ were added as internal standard elements for correction of instrumental drift and matrix effects. Blank intensities for the studied elements were at least two orders of magnitude lower than the sample intensities. The behavior of the REY during sorption is described by the apparent bulk distribution coefficient ${ }_{a p p} D^{R E Y}$ (Bau, 1999), which is the amount of REY sorbed by $\mathrm{Mn}$ (hydr)oxide (the filter residues) divided by the amount of REY retained in solution (the filtrates):

$$
\text { Eq. 1: }{ }_{a p p} D^{R E Y}=[R E Y]_{M n} \text { (hydr)oxide } /[R E Y]_{\text {solution }}
$$

\subsection{Speciation modeling}

The speciation calculations were performed using the computer program PHREEQC (Parkhurst and Appelo, 1999) using the NAGRA/PSI data base (Hummel et al., 2002) which was modified to include well-accepted infinite-dilution $\left(25^{\circ} \mathrm{C}\right)$ stability constants for REE inorganic complexes (i.e., in our study, hydroxide; Klungness and Byrne, 2000; and carbonates; Luo and Byrne, 2004), inifinite dilution stability constants for complexes with DFOB (Christenson and Schijf, 2011), and surface complexation with hydrous manganese oxides (Pourret and Davranche, 2013). Experimental data for the $\mathrm{Ce}(\mathrm{IV})$ DFOB complexation constant are not available. Yoshida et al. (2004) estimated that $\log \left(\mathrm{K}_{\mathrm{Ce}(\mathrm{IV})} / \mathrm{K}_{\mathrm{Ce}(\mathrm{III})}\right)$ with $\mathrm{DFOB}$ is about $25-30$. The $\mathrm{Ce}(\mathrm{III})$-DFOB stability constant $\mathrm{K}_{\mathrm{f}}$ can be approximated at about $10^{11}$ based on extrapolation from $\operatorname{Pr}$ (III)-DFOB and $\mathrm{Nd}(\mathrm{III})$-DFOB as shown in Fig. 2, which would place Ce(IV)-DFOB stability constants in the very high range of $10^{36}$ to $10^{41}$. For the speciation modeling and the SCM, we used a conservative estimate of the Ce(IV)-DFOB stability constant of $10^{36}$. Manganese was considered to precipitate as hydrous manganese oxide instantly and $\mathrm{Mn}^{2+}$-DFOB complexes were not considered because it did not prevent $\mathrm{Mn}^{2+}$ oxidation precipitation as $\mathrm{Mn}$ (hydr)oxides.

\section{Results}




\subsection{Experimental data}

The sorption experiments were conducted as time-series experiments with sampling intervals of $6.5 \mathrm{~min}, 15 \mathrm{~min}, 30 \mathrm{~min}, 60 \mathrm{~min}, 120 \mathrm{~min}$ and $240 \mathrm{~min}$. Figure 3 shows the REY distribution pattern of the siderophore-bearing solution (Fig. 3a) and of the filter residues (Mn (hydr)oxide fraction; Fig. 3b), normalized to the sums of REY recovered in the solution and the filter residues. All filtrates have a very pronounced positive $\mathrm{Ce}$ anomaly. The siderophore solution also exhibits a concave downward LREY pattern and a minor positive $Y$ anomaly for incubation times longer than 6.5 min. Solution concentrations of all REY decrease progressively with increasing incubation times with $\mathrm{La}, \mathrm{Pr}$ and $\mathrm{Nd}$ being close to the lower limit of determination in the 120 and $240 \mathrm{~min}$ experiments. In marked contrast, the filter residues exhibit distinct negative $\mathrm{Ce}$ anomalies and a depletion of the HREY from Gd onward.

Figure 4a shows the apparent distribution coefficients calculated following Eq. 1, while Fig. $4 b$ shows $Y b$-normalized ${ }_{a p p} D^{R E Y}$. The distribution coefficients show distinct features that are present to certain extents in all conducted experiments. The patterns of the apparent distribution coefficient show a smooth downward curved slope declining less intensively towards the HREY, starting with app $D^{R E Y}=15-70$ for $L a$ and ending with ${ }_{\text {app }} \mathrm{D}^{\mathrm{REY}}=0.2-0.8$ for Lu. Cerium is decoupled from its strictly trivalent neighbors $\mathrm{La}$ and $\mathrm{Pr}$ and shows a distinct and very pronounced negative Ce anomaly, i.e., Ce is less efficiently sorbed by $\mathrm{Mn}$ (hydr)oxides in the presence of siderophores than its strictly trivalent LREY neighbors. Negative $Y$ anomalies are typical of all app $D^{R E Y}$ patterns except for the $6.5 \mathrm{~min}$ experiment; $\mathrm{Y} / \mathrm{Ho}$ ratios decrease with increasing incubation time. Ytterbium-normalized ${ }_{a p p} D^{R E Y}$ patterns (Fig. 4b) show a steeply declining slope from LREY to HREY and a large negative $\mathrm{Ce}$ anomaly and a minor $\mathrm{Y} / \mathrm{Ho}$ fractionation. Most importantly, Yb-normalized patterns (Fig. 4b) indicate that the REY are not fractionated further after 15 minutes incubation time which demonstrates that the experimental system reaches steady-state fairly quickly.

All experiments presented in this study were run in duplicate. Error bars are plotted in figures $3 \mathrm{a}$ and $3 \mathrm{~b}$ as well as in figure 4 . While the LREY have slightly higher fluctuations than HREY, most error bars are smaller than the symbol sizes, indicating the good reproducibility of the experimental results. Larger deviations of the distribution coefficients with the LREY are expected due to element abundance in the filtrates approaching the detection limit of the utilized mass spectrometer. The LREY are almost completely removed from solution in the first minutes of the experiments due to the rapid formation of and sorption by Mn (hydr)oxides. Sorption of HREY significantly slows down after 15 min. After 240 minutes, about $100 \%$ to $90 \%$ of La to Sm and $90 \%$ to $40 \%$ of $\mathrm{Eu}$ to Lu are sorbed.

\subsection{Surface complexation modeling}

In order to verify our experimental data and to validate the effect of DFOB on the sorption behavior of REY, we performed speciation and surface complexation modeling 
(SCM) in presence as well as in absence of siderophores using thermodynamic data of Christenson and Schijf (2011).. Speciation modeling of the REY in solution shows that the LREY(III) are mostly present as hydroxide species and only $<10 \%$ are present as LREY(III)-HDFOB ${ }^{+}$species. A significantly larger fraction of MREY(III) to HREY(III) is complexed by DFOB (10-40\%) (Fig. 6). The fraction of REY(III) complexed by DFOB increases towards the HREY and the pattern mimics the stability constants for REY(III) with DFOB as shown in figure 2. According to the model, any $\mathrm{Ce}(\mathrm{IV})$ present in solution is immediately complexed by DFOB due to the about 25 orders of magnitude higher DFOB stability constants with $\mathrm{Ce}(\mathrm{IV})$ compared to $\mathrm{Ce}(\mathrm{III})$.

We also modeled surface complexation of REY(III) sorption onto $\mathrm{MnO}_{2}$ in presence and absence of the DFOB siderophore, respectively, using a diffuse double layer surface complexation model (Pourret and Davranche, 2013). Data shown in figure 6 demonstrates that in absence of DFOB, about $5-20 \%$ of LREY and up to $65 \%$ of HREY should be surface-complexed on $\mathrm{MnO}_{2}$. This results in LREY-depletion in the solid phase with an enrichment of the HREY over the LREY, similar to what was found experimentally by e.g., Ohta \& Kawabe, (2001). Redox reactions involving Ce oxidation were not considered in this modeling step. The modeled REY distribution exhibits minima at $\mathrm{Nd}$, Gd and Lu, very similar to the $2^{\text {nd }}, 3^{\text {rd }}$ and $4^{\text {th }}$ segment of the M-type tetrad effects (Masuda et al., 1987; Akagi et al., 1993; Minami et al., 1998) observed in sorption experiments with $\mathrm{MnO}_{2}$ at higher $\mathrm{pH}$ (Ohta and Kawabe, 2001; Pourret and Davranche, 2013). We also modeled REY sorption onto $\mathrm{MnO}_{2}$ in presence of the siderophore DFOB. While the SCM shows similar fractionation trends as observed in our experiments, i.e., the $\mathrm{Mn}$ phase is enriched in LREY and depleted in HREY and shows a significant negative $\mathrm{Ce}$ anomaly, the absolute percentages of LREY sorbed are significantly higher in our experiments compared to the theoretical model. This is mainly due to the fact that (i) we modeled REY sorption by a specific mineral phase $\left(\mathrm{MnO}_{2}\right)$ instead of by an illdefined mineral assemblage (Mn (hydr)oxides), which may occur in many varieties and the corresponding physicochemical properties may thus be highly variable (Tonkin et al., 2004), (ii) the SCM itself needs to be improved with more experimental data as it was defined for specific conditions (Pourret and Davranche, 2013), (iii) $\mathrm{LnOH}^{+}$were not considered to sorb onto $\mathrm{MnO}_{2}$ and (iv) ternary surface complexes were not considered However, despite these shortcomings, the SCM qualitatively supports the experimental results.

\section{Discussion}

We demonstrated that sorption of REY onto Mn (hydr)oxides is constrained to the LREY if the siderophore DFOB is present in the solution during precipitation of $\mathrm{Mn}$ (hydr)oxides, while the HREY (including $Y$ ) and the redox-sensitive lanthanoid $\mathrm{Ce}$ are preferentially retained in solution. As shown in figures 3 and 4 , complexation with DFOB prevents $\mathrm{Ce}$ from being sorbed onto the precipitating $\mathrm{Mn}$ (hydr)oxide, which eventually 
leads to the formation of pronounced positive $\mathrm{Ce}$ anomalies in the solution and large negative $\mathrm{Ce}$ anomalies in the $\mathrm{Mn}$ (hydr)oxides. After 30 minutes, a small fraction of sorbed Ce is re-solubilized (Fig 3). The SCM supports the hypothesis that DFOB has a strong effect on the sorption behavior of particle-reactive REY during sorption onto $\mathrm{Mn}$ (hydr)oxides and that DFOB produces trace element patterns with HREY depletion, enrichment of LREY, and a negative Ce anomaly in the solid phase.

Ohta and Kawabe (2001) experimentally showed that at circumneutral $\mathrm{pH}$ in the absence of organic compounds $\mathrm{Ce}^{3+}$ is oxidized to $\mathrm{Ce}^{4+}$ during sorption onto $\mathrm{MnO}_{2}$, and that this $\mathrm{MnO}_{2}$ exhibits positive Ce anomalies. This behavior is well-known from natural systems such as hydrogenetic Fe-Mn crusts and Fe-Mn nodules that precipitated from seawater (Bau et al., 2014, and references therein). In marked contrast, our results reveal that in presence of the DFOB siderophore, a negative $\mathrm{Ce}$ anomaly develops on the precipitating $\mathrm{Mn}$ (hydr)oxide. Although $\mathrm{Ce}(\mathrm{III})$-DFOB stability constants were not determined by Christenson and Schijf (2011), these can be estimated by extrapolating from $\operatorname{Pr}(\mathrm{III})$-DFOB and $\mathrm{Nd}(\mathrm{III})-\mathrm{DFOB}$ (as indicated by the dashed line in Fig. 2). Stability constants of metal-DFOB complexes are positively correlated to the ionic potential (i.e., $\mathrm{z} / \mathrm{r}$ ratio) of the complexed metal (Hernlem et al., 1999; Kraemer et al., 2014). A metal in a higher oxidation state, therefore, can be expected to form more stable complexes with DFOB than its reduced form(s). Thus, Ce(IV) should form considerably more stable complexes with DFOB than $\mathrm{Ce}$ (III) and its REY(III) neighbours due to its higher ionic potential. Indeed, Cerium(IV)-DFOB complex stability constants are estimated to be at least as stable as those of Fe(III)-DFOB complexes (Ohnuki and Yoshida, 2012) and Yoshida et al. (2004) suggested the difference between Ce(IV)-DFOB and Ce(III)-DFOB complex stabilities to be at least in the range of 25-30 orders of magnitude. In our experiments, we observed significant decoupling of redox-sensitive Ce from its LREY(III) neighbours, which is only possible if $\mathrm{Ce}$ had changed its redox state in the presence of DFOB. Oxidative scavenging of $\mathrm{Ce}$ by the $\mathrm{Mn}$ (hydr)oxide is obviously prevented, as shown by its negative $\mathrm{Ce}$ anomalies (Fig. $\mathrm{x}$ ).

There are two mechanisms described in the literature that may explain oxidation of $\mathrm{Ce}$ in the presence of DFOB. Duckworth and Sposito (2005) suggested that complexation with DFOB significantly lowers the oxidation potential of the complexed metal, which can then be oxidized rapidly by ambient air within the ligand. This process makes the complex even more stable (see Hernlem et al., 1999; Kraemer et al., 2014) and is used to explain the oxidation of $\mathrm{Mn}$ (II) to $\mathrm{Mn}$ (III) within DFOB complexes (Duckworth and Sposito, 2005). In the specific case of REY-Mn-DFOB interaction, as studied here, $\mathrm{Ce}$ (III) is rapidly bound by DFOB. The complexation lowers the oxidation potential of $\mathrm{Ce}$ (III) significantly and thus ambient air is able to oxidize $\mathrm{Ce}$ (III) to $\mathrm{Ce}(\mathrm{IV})$ within the ligand. The drastically increased complex stability then effectively shields $\mathrm{Ce}$ (IV) and prevents its scavenging by $\mathrm{Mn}$ (hydr)oxides. In this case, DFOB can be regarded as a 'catalyst' for the oxidation of redox-sensitive elements. 
"Air-oxidation" of $\mathrm{Ce}$ is also involved in the siderophore redox pump mechanism described by Bau et al. (2013) and Kraemer et al. (2015), which explains the formation of positive $\mathrm{Ce}$ anomalies in leaching solutions during experimental water-rock interaction with siderophore-bearing solutions. Here, $\mathrm{Ce}$ (III) is released from pristine igneous rocks into solution along with other REY(III) and a redox equilibrium establishes between $\mathrm{Ce}^{3+}{ }_{\text {aq }}$ and $\mathrm{Ce}^{4+}{ }_{\text {aq }}$ in the interface of the mineral and the solution. The redox equilibrium is defined by the oxygen fugacity of the studied system. The often minute amount of $\mathrm{Ce}^{4+}$ aq present in solution is then immediately bound to the siderophore ligand due to the fact that stability constants of tetravalent Ce with DFOB are more than twenty orders of magnitude higher than those of trivalent $\mathrm{Ce}$ with $\mathrm{DFOB}$. The resulting redox disequilibrium between $\mathrm{Ce}^{3+}{ }_{\text {aq }}$ and $\mathrm{Ce}^{4+}{ }_{\text {aq }}$ promotes continuous oxidation of $\mathrm{Ce}^{3+}{ }_{\text {aq }}$ to replenish the $\mathrm{Ce}^{4+}$ aq lost to the $\mathrm{Ce}(\mathrm{IV})-\mathrm{DFOB}$ complex. With increasing incubation time, more and more $\mathrm{Ce}(\mathrm{IV})$ is complexed by the siderophore and thereby prevented from sorption onto Mn (hydr)oxide.

While both mechanisms (i.e. air-oxidation within the DFOB ligand and the siderophore-redox pump) may explain the element fractionation patterns observed in the scavenging experiments presented here, only the siderophore redox pump can explain the positive $\mathrm{Ce}$ anomalies and the Th-U fractionation observed during leaching of igneous rocks with DFOB-bearing solutions (as described by Kraemer et al., 2015). Preferential mobilization of $\mathrm{Ce}$ and $\mathrm{U}$, which produces positive $\mathrm{Ce}$ anomalies and unusually low $\mathrm{Th} / \mathrm{U}$ ratios in DFOB-bearing leaching solutions can neither be explained by a process that involves congruent release of $\mathrm{Ce}(\mathrm{III})$ and $\mathrm{U}$ (IV) from rocks and minerals along with other REY(III) and Th(IV), respectively, nor by air-oxidation of $\mathrm{Ce}$ and $\mathrm{U}$ within the DFOB ligand.

The case is clearer for the fractionation of LREY from HREY, that occurs during our experiments. Here, the heavy REY form complexes with DFOB that are several orders of magnitude more stable than those with the LREY (see stability constants in Fig. 2). Similarly to $\mathrm{Ce}(\mathrm{IV})$, the strictly trivalent HREY also remain in solution and, in contrast to the redox-insensitive LREY, are also protected from scavenging by the Mn (hydr)oxides. The distribution coefficients in the time-series experiments indicate that there is subordinate, yet constant sorption and (re-)solubilization on the surface sites, which is facilitated by the direct competition of sorption with the REY-DFOB complexation in solution. Desferrioxamine-B and $\mathrm{Mn}$ (oxyhydr)oxide, therefore, act as effective antagonists in the competition for dissolved REY. However, the radius-controlled behavior observed in the stability constants of strictly trivalent REY with DFOB is mirrored in the apparent bulk distribution coefficients obtained in our experiments (Fig. 4a+b). While REY are still sorbed and desorbed after an incubation time of $15 \mathrm{~min}$, the fractionation of LREY from HREY has already reached steady-state, as shown in Fig. 4.b.

Numerous studies have shown that the presence of DFOB enhances mineral dissolution and mobilization of trace metals from specific minerals or igneous and sedimentary rocks (i.e., Liermann et al., 2000; Brantley et al., 2001; Neaman et al., 2006; 
Duckworth and Sposito, 2007; Bau et al., 2013; Akafia et al., 2014; Kraemer et al., 2015). It should be emphasized that DFOB is also highly efficient in binding $\mathrm{Mn}$ (II) and $\mathrm{Mn}$ (III) (Duckworth and Sposito, 2005a; Duckworth and Sposito, 2005b). Although we estimate that a certain amount of $\mathrm{Mn}$ is complexed by the DFOB ligand in our experimental solution, Mn still precipitates from solution and the effect of Mn-DFOB interaction on the REY fractionation in presence of DFOB and precipitating Mn (hydr)oxide is minor to negligible as seen in the experimental results of this study.

Ohta and Kawabe (2001) showed in inorganic experiments that sorption of REY by $\mathrm{Mn}$ oxide and hydroxide particles leads to positive $\mathrm{Ce}$ anomalies and significant $\mathrm{M}$-type tetrad patterns. Bau and Koschinsky (2009) showed that $\mathrm{Ce}$ is considerably sorbed by naturally-occurring $\mathrm{Mn}$ and Fe oxides. This process (referred to as oxidative scavenging) leads to the pronounced enrichment of Ce relative to other LREY at the surface of hydroxide particles, and hence to the formation of a positive Ce anomaly. These REY patterns do not form in the presence of organic acids (Davranche et al., 2005; Davranche et al., 2008; see Fig. 1) or are significantly modified in the presence of the siderophore DFOB, as demonstrated in this study. The small $Y$ anomalies which indicate slight fractionation of $Y$ from its geochemical twin Ho, show that the presence of specific organic ligands such as DFOB is capable of altering the $\mathrm{Y}$-Ho ratio in hydroxide mineral structures and the ambient aqueous solution.

Davranche et al. (2005) conducted REY sorption experiments in the presence of humic acid, which is in some environments one of the most abundant organic acids. They found that sorption of humate-REY complexes onto $\mathrm{MnO}_{2}$ strongly suppresses oxidative scavenging of Ce. Davranche et al. $(2005 ; 2008)$ also demonstrated that complexation of trivalent REY with humate ligands reduces and suppresses the development of M-type lanthanide tetrad effects during sorption onto manganese dioxide. Our results show that sorption in presence of biogenic siderophores such as DFOB can in fact even lead to the complete lack of lanthanide tetrad effects.

The results of this study might help explain certain geochemical peculiarities observed for REY partitioning between natural waters and their chemical precipitates. Loges et al. (2012) published analytical data for secondary hydrothermal vein fluorites, which are accompanied by syngenetic Mn oxides. These $\mathrm{Mn}$ oxides show extremely negative $\mathrm{Ce}$ anomalies of up to four orders of magnitude. This agrees with the mine drainage waters and the surface waters which both show high amounts of dissolved organic carbon, indicating high concentrations of organic ligands in the solutions which are percolating through the fracture network. Loges et al. (2012) suggested that the large negative $\mathrm{Ce}$ anomalies observed in the $\mathrm{Mn}$ oxide precipitates may be caused by siderophore-enriched surface water percolating through the vein system. We here show that the presence of the DFOB siderophore during precipitation of Mn (hydr)oxides may produce negative $\mathrm{Ce}$ anomalies in the solid phase and positive $\mathrm{Ce}$ anomalies in the solution corroborating the explanation put forward by Loges et al. (2012). Tanaka et al. (2012) showed that sorption of REE on biogenic Mn oxide produced by the fungus 
Acremonium sp. leads to development of $\mathrm{Ce}$ anomalies. At low $\mathrm{pH}(<5)$, positive $\mathrm{Ce}$ anomalies form in the biogenic $\mathrm{Mn}$ oxides, whereas at circumneutral $\mathrm{pH}$, negative $\mathrm{Ce}$ anomalies developed in the biogenic $\mathrm{Mn}$ oxides. These negative $\mathrm{Ce}$ anomalies were attributed to $\mathrm{Ce}$ (III) oxidation on the surface site of the biogenic Mn oxide and subsequent complexation of $\mathrm{Ce}(\mathrm{IV})$ with organic ligands. These organic ligands have not been identified in the study of Tanaka et al. (2012), but several studies exist that show that fungi and also Acremonium species are able to produce and excrete siderophore compounds (e.g., Leong and Winkelmann, 1998; Haas, 2003; Prathyusha et al., 2015). Ohnuki et al. (2015) stressed the importance of microbial cells in affecting redox processes by elucidating the role of microorganisms on $\mathrm{Ce}$ (III) oxidation during $\mathrm{Ce}$ sorption onto synthetic Mn oxides in presence of cells of Pseudomonas fluorescens. They conclude that $\mathrm{Ce}$ (III) is associated with microbial cell surfaces and forms Ce phosphate nanoparticles, which are responsible for suppressing the oxidation of $\mathrm{Ce}$ (III) during sorption. Brantley et al. (2001) showed that bacteria preferentially remove HREE from hornblende minerals and that $\mathrm{Ce}$ (III) is partially oxidized to $\mathrm{Ce}(\mathrm{IV})$ in the presence of some bacteria. Yu et al. (2016) demonstrated that Ce can be decoupled from its REY neighbors by associating with a biomolecule produced from a fungus. They explicitly state that this biomolecule is not associated with Fe or REY(III), which means that not only ligands with a high affinity for $\mathrm{Fe}$ (III) (i.e., siderophores) facilitate Ce decoupling, but that other groups of biologically produced molecules (metallophores; Kraemer et al., 2014) exist in nature, which apparently are capable of facilitating geochemical twin fractionation by promoting oxidation of redox-sensitive trace elements like Ce (this study, Yu et al., 2016 and others) or $U$ (Kraemer et al., 2015). We suggest that siderophores or metallophores may affect REY signatures of natural waters and their precipitates (i.e., oxide and hydroxide minerals) in environments which favor the production of metallophores (i.e., nutrient deficiency and/or heavy metal contamination).

\section{Conclusion}

We showed that a biogenic extracellular compound like the siderophore DFOB, which is abundant in many natural environments, effectively alters the particle reactivity of REY and enhances the mobility of (i) $\mathrm{HREY}$ (III) by strong ligand binding and (ii) $\mathrm{Ce}$ (IV) by oxidation of $\mathrm{Ce}$ (III) and formation of very stable $\mathrm{Ce}$ (IV) DFOB complexes in solution. The experimental and modeling data presented in this study strongly suggest that the presence of the siderophore DFOB in natural aqueous solutions such as seawater, river water, marine and terrestrial pore waters and even low temperate hydrothermal systems may alter not only the biological availability of bioessential trace metals, but that DFOB also effectively modifies the particle-reactivity and promotes or prevents the removal of certain trace elements from solution by mechanisms such as sorption onto and/or structural incorporation into $\mathrm{Mn}$ (hydr)oxides.

Our experimental results demonstrate that biogenic organic ligands, such as hydroxamate siderophores, may produce solutions with positive $\mathrm{Ce}$ anomaly (Bau et al., 
2013; Kraemer et al., 2015) and may even counteract the surface oxidation of Ce catalyzed by $\mathrm{Mn}$ (hydr)oxides and the preferred sorption by such metal (hydr)oxides. Furthermore, the observed fractionation of HREY from LREY during Mn (hydr)oxide coprecipitation in presence of a biogenic ligand may point to a useful process for industrial separation of heavy REY from light REY.

\section{References}

Akafia M. M., Harrington J. M., Bargar J. R. and Duckworth O. W. (2014) Metal Oxyhydroxide Dissolution as Promoted by Structurally Diverse Siderophores and Oxalate. Geochim. Cosmochim. Acta 141, 258-269. Available at: http://www.sciencedirect.com/science/article/pii/S0016703714004256 [Accessed July 10, 2014].

Akagi T., Shabani M. B. and Masuda A. (1993) Lanthanide tetrad effect in kimuraite [CaY2(CO3)4 - 6H2O]: Implication for a new geochemical index. Geochim. Cosmochim. Acta 57, 2899-2905. Available at: http://www.sciencedirect.com/science/article/pii/001670379390397F [Accessed November 23, 2015].

Baldwin G. J., Turner E. C., Kamber B. S. and Colpron M. (2012) A new depositional model for glaciogenic Neoproterozoic iron formation: insights from the chemostratigraphy and basin configuration of the Rapitan iron formation 11 Northwest Territories Geoscience Office Contribution 0052. Can. J. Earth Sci. 49, 455-476. Available at: http://www.nrcresearchpress.com/doi/abs/10.1139/e11-066.

Bau M. (1996) Controls on the fractionation of isovalent trace elements in magmatic and aqueous systems: evidence from $\mathrm{Y} / \mathrm{Ho}, \mathrm{Zr} / \mathrm{Hf}$, and lanthanide tetrad effect. Contrib. to Mineral. Petrol. 123, 323-333. Available at:

http://www.springerlink.com/openurl.asp?genre=article\&id=doi:10.1007/s004100050 159.

Bau M. (1999) Scavenging of dissolved yttrium and rare earths by precipitating iron oxyhydroxide: Experimental evidence for $\mathrm{Ce}$ oxidation, Y-Ho fractionation, and lanthanide tetrad effect. Geochim. Cosmochim. Acta 63, 67-77. Available at: http://linkinghub.elsevier.com/retrieve/pii/S0016703799000149.

Bau M. and Alexander B. W. (2006) Preservation of primary REE patterns without Ce anomaly during dolomitization of Mid-Paleoproterozoic limestone and the potential re-establishment of marine anoxia immediately after the "Great Oxidation Event." South African J. Geol. 109, 81-86. Available at: http://sajg.geoscienceworld.org/content/109/1-2/81.full [Accessed November 23, 2015].

Bau M. and Dulski P. (1996) Distribution of yttrium and rare-earth elements in the Penge and Kuruman iron-formations, Transvaal Supergroup, South Africa. Precambrian Res. 79, 37-55. Available at: http://www.sciencedirect.com/science?_ob=Mlmg\&_imagekey=B6VBP-3VWNJR7T-

3\&_cdi $=5932 \&$ user $=1634476 \&$ _pii $=0301926895000879 \&$ origin=gateway $\&$ cover Date $=07 / 31 / 1996 \&$ sk=999209998\&view $=c \& w c h p=d G L b V z W-$ zSkzV\&md5=fda597aef725d49794a1 eb3e69d45ce7\&ie=/sdarticle.pdf.

Bau M. and Koschinsky a (2009) Oxidative scavenging of cerium on hydrous Fe oxide: Evidence from the distribution of rare earth elements and yttrium between $\mathrm{Fe}$ oxides 
and $\mathrm{Mn}$ oxides in hydrogenetic ferromanganese crusts. Geochem. J. 43, 37-47. Available at: http://www.jstage.jst.go.jp/article/geochemj/43/1/37/_pdf.

Bau M., Schmidt K., Koschinsky A., Hein J., Kuhn T. and Usui A. (2014) Discriminating between different genetic types of marine ferro-manganese crusts and nodules based on rare earth elements and yttrium. Chem. Geol. 381, 1-9. Available at: http://www.sciencedirect.com/science/article/pii/S0009254114002423 [Accessed February 5, 2015].

Bau M., Tepe N. and Mohwinkel D. (2013) Siderophore-promoted transfer of rare earth elements and iron from volcanic ash into glacial meltwater, river and ocean water Earth Planet. Sci. Lett. 364, 30-36. Available at: http://linkinghub.elsevier.com/retrieve/pii/S0012821X13000101 [Accessed March 12, 2013].

Bau M., Usui A., Pracejus B., Mita N., Kanai Y., Irber W. and Dulski P. (1998) Geochemistry of low-temperature water - rock interaction : evidence from natural waters, andesite, and iron-oxyhydroxide precipitates at Nishiki-numa iron-spring, Hokkaido, Japan. Chem. Geol. 151, 293-307. Available at: http://www.sciencedirect.com/science/article/pii/S0009254198000862 [Accessed October 21, 2014].

Brantley S. L., Liermann L., Bau M. and Wu S. (2001) Uptake of Trace Metals and Rare Earth Elements from Hornblende by a Soil Bacterium. Geomicrobiol. J. 18, 37-61.

Braud A., Geoffroy V., Hoegy F., Mislin G. L. A. and Schalk I. J. (2010) Presence of the siderophores pyoverdine and pyochelin in the extracellular medium reduces toxic metal accumulation in Pseudomonas aeruginosa and increases bacterial metal tolerance. Environ. Microbiol. Rep. 2, 419-25. Available at: http://www.ncbi.nlm.nih.gov/pubmed/23766115 [Accessed October 15, 2015].

Carlo E. H. D. E. and Wen X. (1998) The Influence of Redox Reactions on the Uptake of Dissolved Ce by Suspended Fe and Mn Oxide Particles. Aquat. Geochemistry 3, 357-389. Available at: http://www.springerlink.com/openurl.asp?genre=article\&id=doi:10.1023/A:10096646 26181.

Christenson E. and Schijf J. (2011) Stability of YREE complexes with the trihydroxamate siderophore desferrioxamine B at seawater ionic strength. Geochim. Cosmochim. Acta 75, 7047-7062. Available at: http://www.sciencedirect.com/science/article/pii/S0016703711005436.

Davranche M., Pourret O., Gruau G., Dia a, Jin D. and Gaertner D. (2008) Competitive binding of REE to humic acid and manganese oxide: Impact of reaction kinetics on development of cerium anomaly and REE adsorption. Chem. Geol. 247, 154-170. Available at: http://linkinghub.elsevier.com/retrieve/pii/S0009254107004573 [Accessed March 12, 2013].

Davranche M., Pourret O., Gruau G. and Dia A. (2004) Impact of humate complexation on the adsorption of REE onto Fe oxyhydroxide. J. Colloid Interface Sci. 277, 271279. Available at: http://www.ncbi.nlm.nih.gov/pubmed/15341835 [Accessed March 12, 2013].

Davranche M., Pourret O., Gruau G., Dia A. and Le Coz-Bouhnik M. (2005) Adsorption of $\mathrm{REE}$ (III)-humate complexes onto MnO2: Experimental evidence for cerium anomaly and lanthanide tetrad effect suppression. Geochim. Cosmochim. Acta 69, 48254835. Available at: http://linkinghub.elsevier.com/retrieve/pii/S0016703705004825.

Duckworth O. and Sposito G. (2007) Siderophore-promoted dissolution of synthetic and biogenic layer-type Mn oxides. Chem. Geol. 242, 497-508. Available at: http://linkinghub.elsevier.com/retrieve/pii/S0009254107002173 [Accessed March 26, 2013].

Duckworth O. W. and Sposito G. (2005) Interactions II . Manganite Dissolution Promoted by Desferrioxamine B. Environ. Sci. Technol. 39, 6045-6051. Available at: http://pubs.acs.org/doi/abs/10.1021/es050276c. 
Duckworth O. W. and Sposito G. (2005) Siderophore-manganese (III) interactions. I. Airoxidation of manganese(II) promoted by desferrioxamine B. Environ. Sci. Technol. 39, 6037-6044.

Frei R., Gaucher C., Poulton S. W. and Canfield D. E. (2009) Fluctuations in Precambrian atmospheric oxygenation recorded by chromium isotopes. Nature 461, 250-3. Available at: http://dx.doi.org/10.1038/nature08266 [Accessed August 24, 2014].

Frei R., Gaucher C., Stolper D. and Canfield D. E. (2013) Fluctuations in late Neoproterozoic atmospheric oxidation - $\mathrm{Cr}$ isotope chemostratigraphy and iron speciation of the late Ediacaran lower Arroyo del Soldado Group (Uruguay). Gondwana Res. 23, 797-811. Available at: http://www.sciencedirect.com/science/article/pii/S1342937X1200202X [Accessed October 24, 2015].

German C. R. and Elderfield H. (1990) Application of the Ce anomaly as a paleoredox indicator: The ground rules. Paleoceanography 5, 823-833. Available at: http://doi.wiley.com/10.1029/PA005i005p00823 [Accessed September 26, 2014].

Haas H. (2003) Molecular genetics of fungal siderophore biosynthesis and uptake: the role of siderophores in iron uptake and storage. Appl. Microbiol. Biotechnol. 62, 316-30. Available at: http://www.ncbi.nlm.nih.gov/pubmed/12759789 [Accessed July 1, 2014].

Höfte M., Buysens S., Koedam N. and Cornelis P. (1993) Zinc affects siderophoremediated high affinity iron uptake systems in the rhizosphere Pseudomonas aeruginosa 7NSK2. Biometals 6 . Available at: http://link.springer.com/10.1007/BF00140108 [Accessed October 26, 2015].

Hummel W., Berner U., Curti E., Pearson F. J. and Thoenen T. (2002) Nagra / PSI Chemical Thermodynamic Data Base 01/01., Parkland, FLorida.

Humphries M. (2013) Rare Earth Elements: The Global Supply Chain.,

Klungness G. D. and Byrne R. H. (2000) Comparative hydrolysis behavior of the rare earths and yttrium: the influence of temperature and ionic strength. Polyhedron 19, 99-107. Available at:

http://www.sciencedirect.com/science/article/pii/S0277538799003320 [Accessed May 21, 2015].

Koeppenkastrop D. and De Carlo E. H. (1992) Sorption of rare-earth elements from seawater onto synthetic mineral particles: An experimental approach. Chem. Geol. 95, 251-263. Available at: http://linkinghub.elsevier.com/retrieve/pii/000925419290015W.

Kraemer D., Kopf S. and Bau M. (2015) Oxidative mobilization of cerium and uranium and enhanced release of "immobile" high field strength elements from igneous rocks in the presence of the biogenic siderophore desferrioxamine B. Geochim. Cosmochim. Acta 165, 263-279. Available at: http://www.sciencedirect.com/science/article/pii/S001670371500383X [Accessed June 22, 2015].

Kraemer S. M. (2004) Iron oxide dissolution and solubility in the presence of siderophores. Aquat. Sci. Res. Across Boundaries 66, 3-18. Available at: http://www.springerlink.com/openurl.asp?genre=article\&id=doi:10.1007/s00027-0030690-5 [Accessed February 27, 2013].

Kraemer S. M., Duckworth O. W., Harrington J. M. and Schenkeveld W. D. C. (2014) Metallophores and Trace Metal Biogeochemistry. Aquat. Geochemistry. Available at: http://link.springer.com/10.1007/s10498-014-9246-7 [Accessed November 19, 2014].

Leong S. A. and Winkelmann G. (1998) Molecular biology of iron transport in fungi. Met. lons Biol. Syst. 35, 147-86. Available at: http://www.ncbi.nlm.nih.gov/pubmed/9444761 [Accessed May 19, 2015].

Liermann L., Kalinowski B., Brantley S. L. and Ferry J. G. (2000) Role of bacterial 
siderophores in dissolution of hornblende. Geochim. Cosmochim. Acta 64, 587602. Available at:

http://www.sciencedirect.com/science/article/pii/S0016703799002884 [Accessed July 8, 2014].

Loges A., Wagner T., Barth M., Bau M., Göb S. and Markl G. (2012) Negative Ce anomalies in $\mathrm{Mn}$ oxides: The role of $\mathrm{Ce} 4+$ mobility during water-mineral interaction. Geochim. Cosmochim. Acta 86, 296-317. Available at: http://linkinghub.elsevier.com/retrieve/pii/S0016703712001597 [Accessed March 12 2013].

Luo Y. R. and Byrne R. H. (2004) Carbonate complexation of yttrium and the rare earth elements in natural waters. Geochim. Cosmochim. Acta 68, 691-699.

Martinez R. E., Pourret O. and Takahashi Y. (2014) Modeling of rare earth element sorption to the Gram positive Bacillus subtilis bacteria surface. J. Colloid Interface Sci. 413, 106-11. Available at: http://www.sciencedirect.com/science/article/pii/S0021979713008667 [Accessed April 24, 2015].

Masuda A. and Akagi T. (1989) Lanthanide tetrad effect observed in leucogranites from China. Geochem. J. 23, 245-253. Available at: https://www.jstage.jst.go.jp/article/geochemj1966/23/5/23_5_245/_article [Accessed November 23, 2015].

Masuda A., Kawakami O., Dohmoto Y. and Takenaka T. (1987) Lanthanide tetrad effects in nature: Two mutually opposite types, W and M. Geochem. J. 21, 119-124. Available at: https://www.jstage.jst.go.jp/article/geochemj1966/21/3/21_3_119/_article [Accessed November 23, 2015].

Mayanna S., Peacock C. L., Schäffner F., Grawunder A., Merten D., Kothe E. and Büchel G. (2015) Biogenic precipitation of manganese oxides and enrichment of heavy metals at acidic soil pH. Chem. Geol. 402, 6-17. Available at: http://www.sciencedirect.com/science/article/pii/S0009254115000777 [Accessed September 24, 2015].

Millero F. J. (1992) Stability constants for the formation of rare earth-inorganic complexes as a function of ionic strength. Geochim. Cosmochim. Acta 56, 3123-3132. Available at: http://www.sciencedirect.com/science/article/pii/001670379290293R [Accessed July 11, 2014].

Minami M., Masuda A., Takahashi K., Adachi M. and Shmizu H. (1998) Y-Ho fractionation and lanthanide tetrad effect observed in cherts. Geochem. J. 32, 405-419.

Neaman A., Chorover J. and Brantley S. L. (2006) Effects of organic ligands on granite dissolution in batch experiments at pH 6. Am. J. Sci. 306, 451-473. Available at: http://www.ajsonline.org/content/306/6/451.short [Accessed March 27, 2015].

Neilands J. B. (1957) Some aspects of microbial iron metabolism. Bacteriol. Rev. 21, 101-11. Available at:

http://www.pubmedcentral.nih.gov/articlerender.fcgi?artid=180889\&tool=pmcentrez \&rendertype=abstract [Accessed October 2, 2013].

O'Brien S., Hodgson D. J. and Buckling A. (2014) Social evolution of toxic metal bioremediation in Pseudomonas aeruginosa. Proc. Biol. Sci. 281, 20140858-. Available at: http://rspb.royalsocietypublishing.org/content/281/1787/20140858 [Accessed October 26, 2015].

Ohnuki T., Jiang M., Sakamoto F., Kozai N., Yamasaki S., Yu Q., Tanaka K., Utsunomiya S., Xia X., Yang K. and He J. (2015) Sorption of Trivalent Cerium by a Mixture of Microbial Cells and Manganese oxides: Effect of Microbial Cells on the Oxidation of Trivalent Cerium. Geochim. Cosmochim. Acta. Available at: http://www.sciencedirect.com/science/article/pii/S0016703715002495 [Accessed May 4, 2015].

Ohnuki T. and Yoshida T. (2012) Interactions of the Rare Earth Elements- 
Desferrioxamine B Complexes with Pseudomonas fluorescens and y-Al2O3. Chem. Lett. 41, 98-100.

Ohta A. and Kawabe I. (2001) REE (III) adsorption onto Mn dioxide (delta-MnO2) and Fe oxyhydroxide: $\mathrm{Ce}$ (III) oxidation by delta-MnO2. Geochim. Cosmochim. Acta 65, 695-703. Available at: http://linkinghub.elsevier.com/retrieve/pii/S0016703700005780.

Parkhurst D. L. and Appelo C. A. J. (1999) User's guide to PHREEQC (Version 2) - A computer program for speciation, batch-reaction, one-dimensional transport, and inverse geochemical calculations.,

Pattan J. N., Pearce N. J. G. and Mislankar P. G. (2005) Constraints in using Ceriumanomaly of bulk sediments as an indicator of paleo bottom water redox environment: A case study from the Central Indian Ocean Basin. Chem. Geol. 221, 260-278. Available at:

http://www.sciencedirect.com/science/article/pii/S000925410500224X [Accessed October 12, 2014].

Pourret O. and Davranche M. (2013) Rare earth element sorption onto hydrous manganese oxide: A modeling study. J. Colloid Interface Sci. 395, 18-23. Available at: http://www.ncbi.nlm.nih.gov/pubmed/23266025 [Accessed March 8, 2013].

Pourret O., Davranche M., Gruau G. and Dia A. (2008) New insights into cerium anomalies in organic-rich alkaline waters. Chem. Geol. 251, 120-127. Available at: http://www.sciencedirect.com/science/article/pii/S000925410800106X [Accessed April 24, 2015].

Prathyusha P., Rajitha Sri A. B., Ashokvardhan T. and Satya Prasad K. (2015) Antimicrobial and Siderophore Activity of the Endophytic Fungus. Int. J. Pharm. Sci. Rev. Res. 30, 84-87.

Quinn K. A., Byrne R. H. and Schijf J. (2006a) Sorption of yttrium and rare earth elements by amorphous ferric hydroxide: Influence of $\mathrm{pH}$ and ionic strength. Mar. Chem. 99, 128-150. Available at: http://linkinghub.elsevier.com/retrieve/pii/S0304420305001891 [Accessed March 12, 2013].

Quinn K. A., Byrne R. H. and Schijf J. (2006b) Sorption of yttrium and rare earth elements by amorphous ferric hydroxide: Influence of solution complexation with carbonate. Geochim. Cosmochim. Acta 70, 4151-4165. Available at: http://www.sciencedirect.com/science/article/B6V66-4KGG1W13/2/d0b4ab2e48432f3484b46188f78f6776.

Quinn K. A., Byrne R. H. and Schijf J. (2007) Sorption of yttrium and rare earth elements by amorphous ferric hydroxide: influence of temperature. Environ. Sci. Technol. 41, 541-546. Available at: http://pubs.acs.org/doi/abs/10.1021/es0618191.

Römheld V. (1991) The role of phytosiderophores in acquisition of iron and other micronutrients in graminaceous species: An ecological approach. Plant Soil 130, 127-134. Available at: http://link.springer.com/10.1007/BF00011867 [Accessed December 13, 2013].

Schijf J., Christenson E. A. and Byrne R. H. (2015) YREE scavenging in seawater: A new look at an old model. Mar. Chem. 177, 460-471. Available at: http://linkinghub.elsevier.com/retrieve/pii/S0304420315001255.

Schijf J. and Marshall K. S. (2011) YREE sorption on hydrous ferric oxide in $0.5 \mathrm{M} \mathrm{NaCl}$ solutions: A model extension. Mar. Chem. 123, 32-43. Available at: http://linkinghub.elsevier.com/retrieve/pii/S0304420310001015.

Tanaka K., Tani Y., Takahashi Y., Tanimizu M., Suzuki Y., Kozai N. and Ohnuki T. (2010) A specific Ce oxidation process during sorption of rare earth elements on biogenic $\mathrm{Mn}$ oxide produced by Acremonium sp. strain KR21-2. Geochim. Cosmochim. Acta 74, 5463-5477. Available at: http://www.sciencedirect.com/science/article/B6V6650J4MJM-5/2/2146a5913a12031bae8b3f1a78675ef5 [Accessed March 12, 2013]. 
Teitzel G. M., Geddie A., De Long S. K., Kirisits M. J., Whiteley M. and Parsek M. R. (2006) Survival and growth in the presence of elevated copper: transcriptional profiling of copper-stressed Pseudomonas aeruginosa. J. Bacteriol. 188, 7242-56. Available at: http://jb.asm.org/content/188/20/7242. short [Accessed October 26, 2015].

Tonkin J. W., Balistrieri L. S. and Murray J. W. (2004) Modeling sorption of divalent metal cations on hydrous manganese oxide using the diffuse double layer model. Appl. Geochemistry 19, 29-53. Available at:

http://www.sciencedirect.com/science/article/pii/S088329270300115X [Accessed May 21, 2015].

Yu Q., Ohnuki T., Tanaka K., Kozai N., Yamasaki S., Sakamoto F. and Tani Y. (2016) Fungus-promoted transformation of lanthanides during the biooxidation of divalent manganese. Geochim. Cosmochim. Acta 174, 1-12. Available at: http://linkinghub.elsevier.com/retrieve/pii/S0016703715006341.

Figures

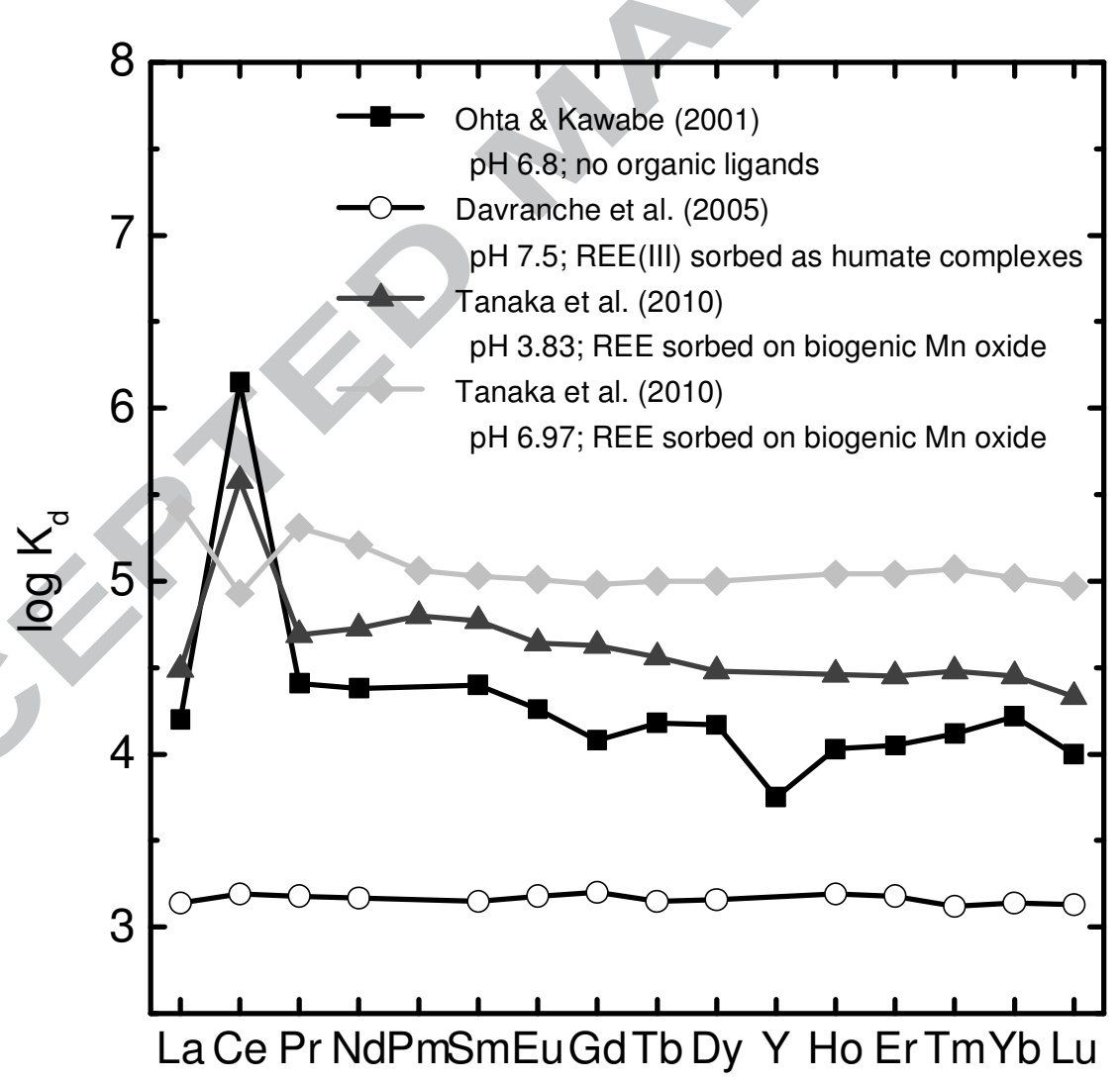

Fig. 1: REY partition coefficients between $\mathrm{MnO}_{2}$ and ambient solution as obtained by sorption experiments conducted by Ohta and Kawabe (2001) without organic ligands, Davranche et al. (2005) with humate ligands and two datasets from Tanaka et al. (2010), where REY were 
sorbed at different pH on biogenic Mn oxides produced by the Acremonium sp strain KR21-2. Note the positive $\mathrm{Ce}$ and negative $\mathrm{Y}$ anomaly in organic-ligand free experiments, the suppression of Ce oxidation when REY are present as REY(III)-humate complexes and the negative Ce anomaly for REY sorption on biogenic Mn oxide at circumneutral pH.

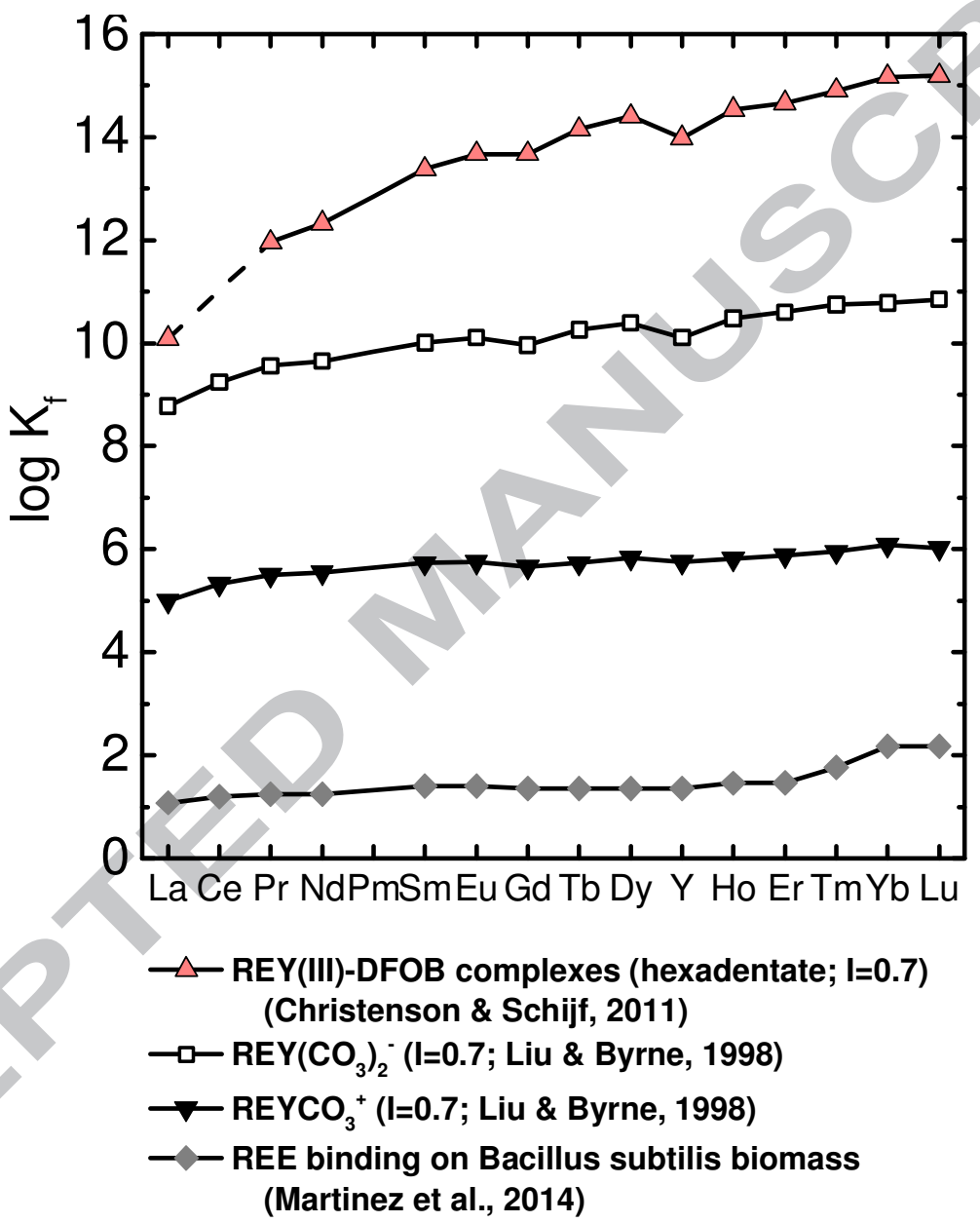

Fig. 2: Equilibrium constants of REY(III) for hexadentate $\left(\log \beta_{3}\right)$ complexes with the siderophore desferrioxamine B (stability constants from Christenson and Schijf, 2011), for mono- and dicarbonate REY(III) complexes and for REE binding by Bacillus subtilis biomass. Note the increasingly ascending slope for hexadentate complexes towards the heavier REY and the lower Y(III)-DFOB complex stability constants compared to Ho(III). 


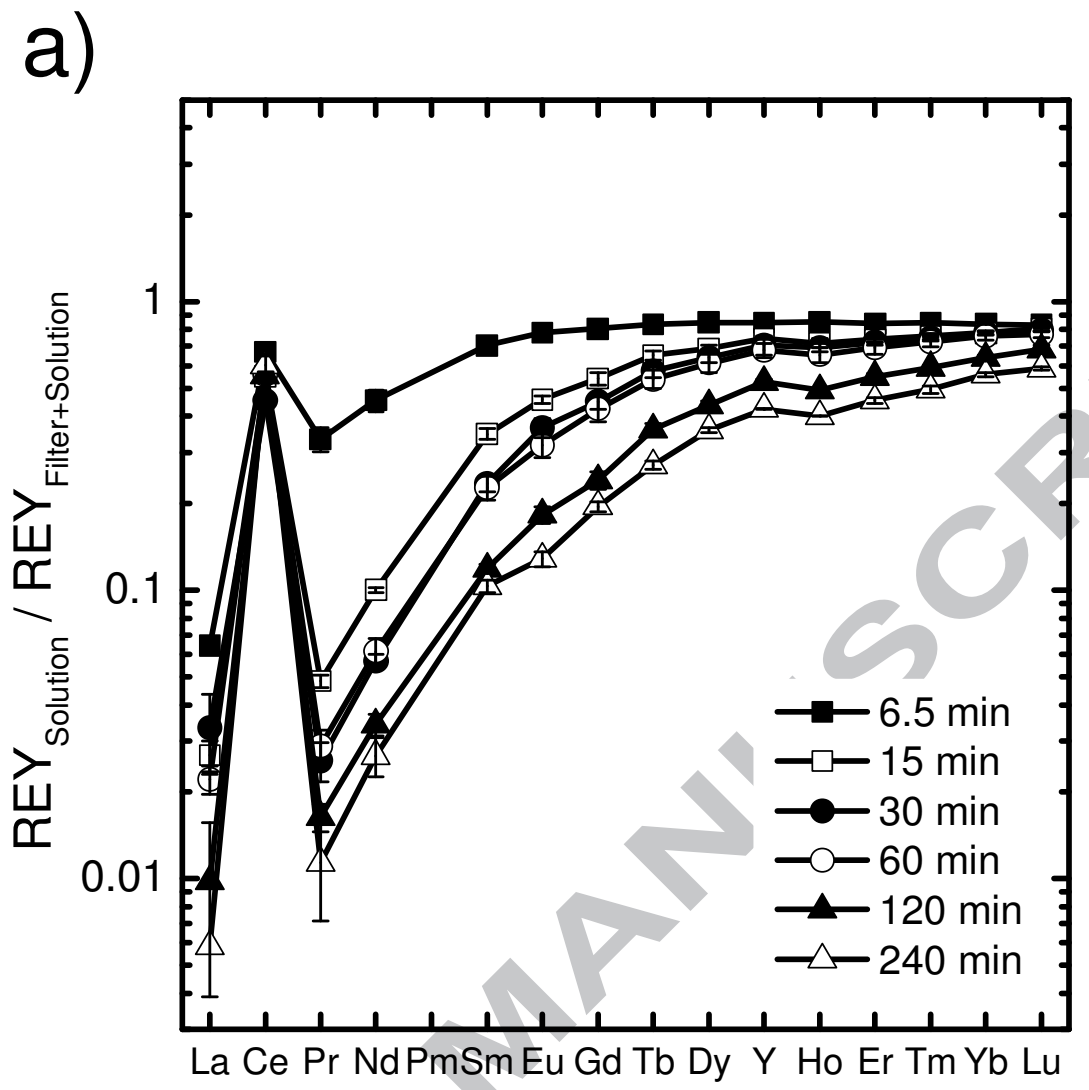




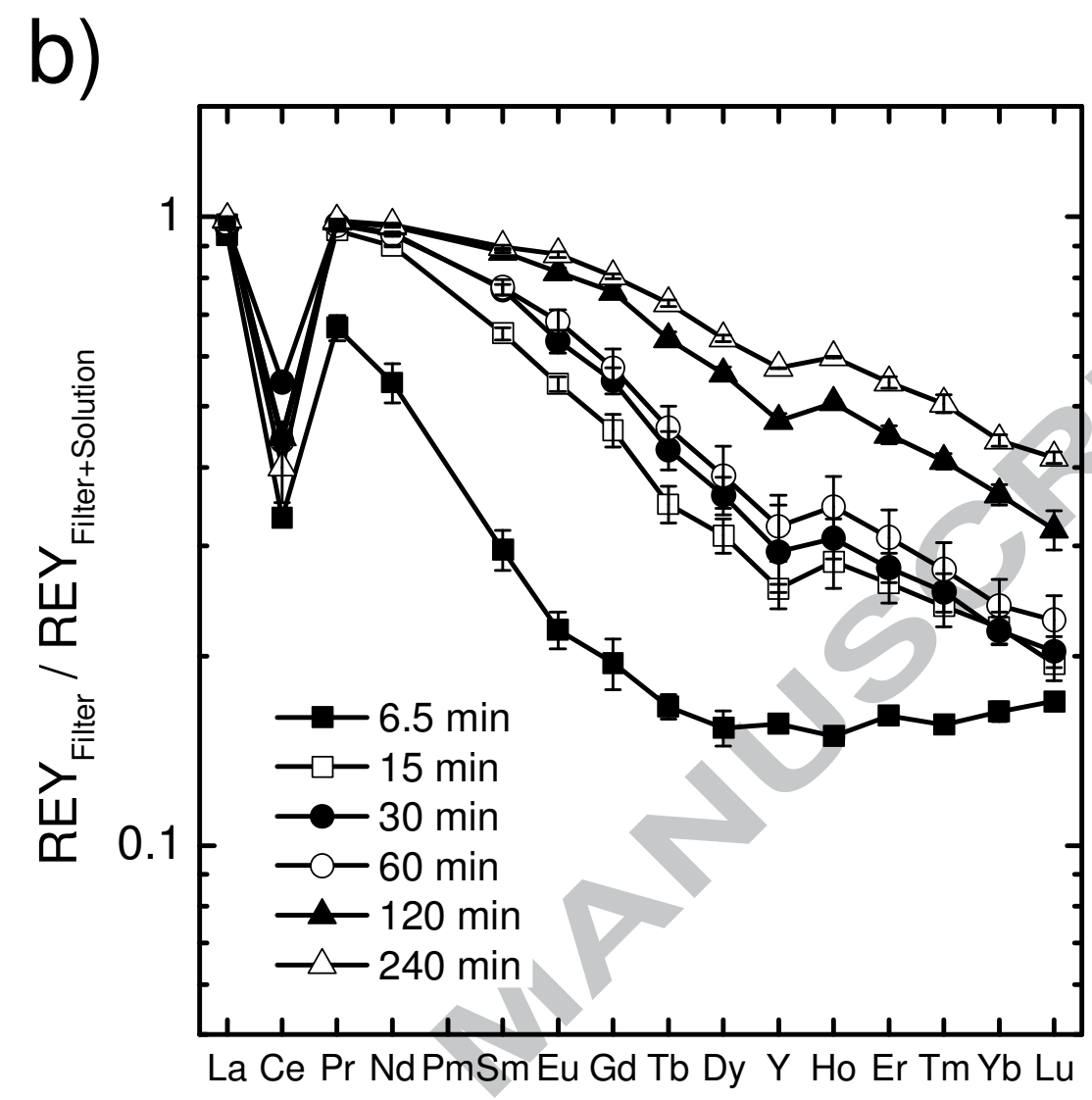

Fig. 3: REY in solution normalized to the sum of REY sorbed by Mn (hydr)oxides and REY in solution (3a) and REY sorbed by Mn (hydr)oxides normalized to the sum of REY sorbed on Mn (hydr)oxides and REY in solution (3b). Note that the larger error bars for La and Pr for 120 and 240 min experiments are caused by element abundance in residual solutions being near detection limit of the ICP-MS measurement. The filtered solutions exhibit pronounced positive Ce anomalies indicating siderophore-mediated oxidation and a REY pattern that mimics the REY-DFOB stability constants determined by Christenson and Schijf (2011). The precipitated (hydr)oxides are depleted in HREY and exhibit a negative Ce anomaly and a small negative $Y$ anomaly. 
a)

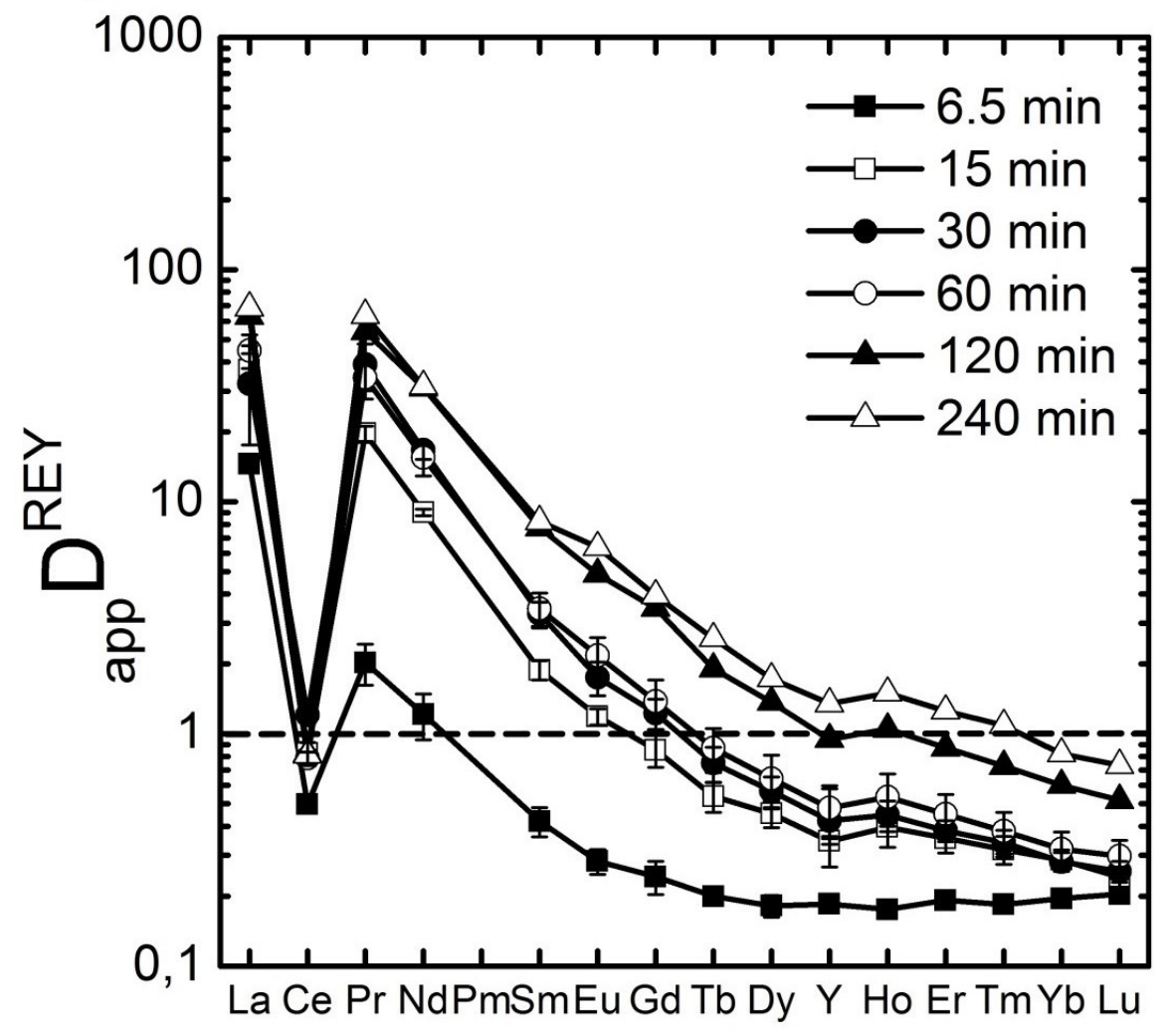




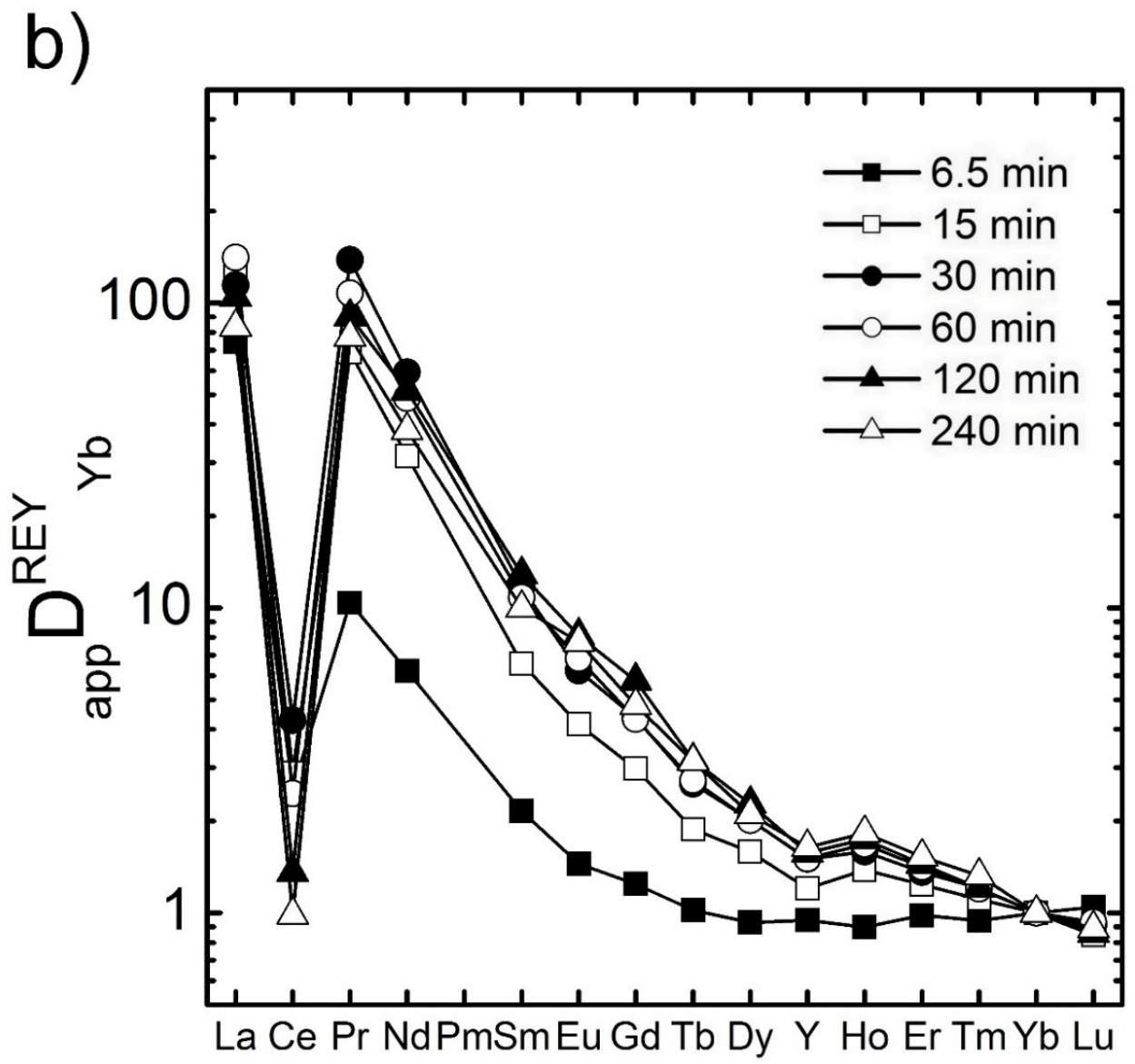

Fig. 4: Apparent bulk distribution coefficient (4a) and Yb-normalized apparent bulk distribution coefficient (4b) of the Mn (hydr)oxides precipitated from an artificial solution with $\sum[R E Y]=0.41$ $\mu \mathrm{mol} / \mathrm{L}, c(\mathrm{Mn})=0.182 \mathrm{mmol} / \mathrm{L}$ and $c(D F O B)=100 \mu \mathrm{mol} / \mathrm{L}$. Note the abundant negative Ce anomalies and the typical downward slope of the coefficient towards HREY. In presence of DFOB, HREY express a high affinity for the solution (app $D^{\text {REY }}<1$ ). Also note the small negative $Y$ anomaly developing with increasing incubation time, which is in accordance to the experimental results of Ohta \& Kawabe (2002) on Mn-REY(III) interaction. 


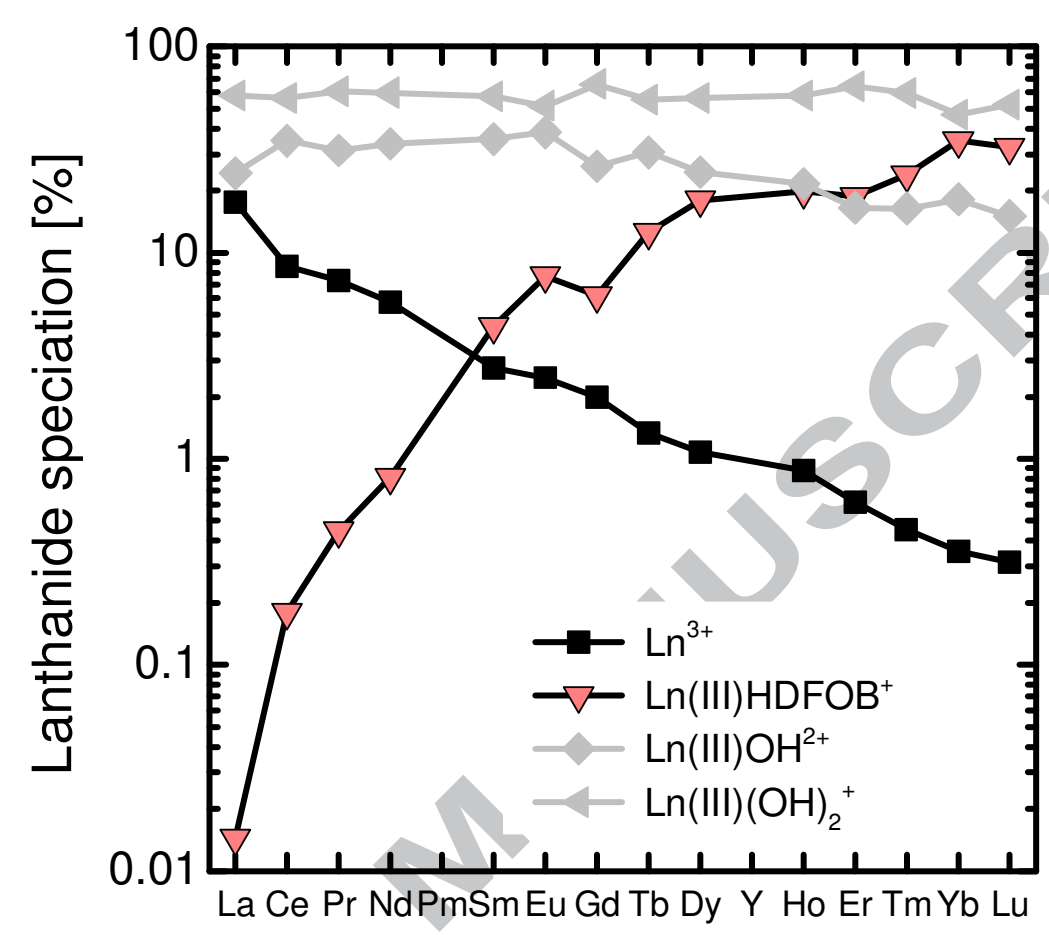

Fig. 5: Lanthanide speciation in experimental solution used in sorption experiments (no Mn precipitated; pH 9). Speciation modeled using PHREEQC 3.3.0. Stability constants obtained by Christenson and Schijf (2011) for REY(III). The Ce(III) stability constant (log $\mathrm{K}_{f}=11.5$ ) was extrapolated from $\mathrm{Nd}$ and $\operatorname{Pr}$ (see Fig. 2). 


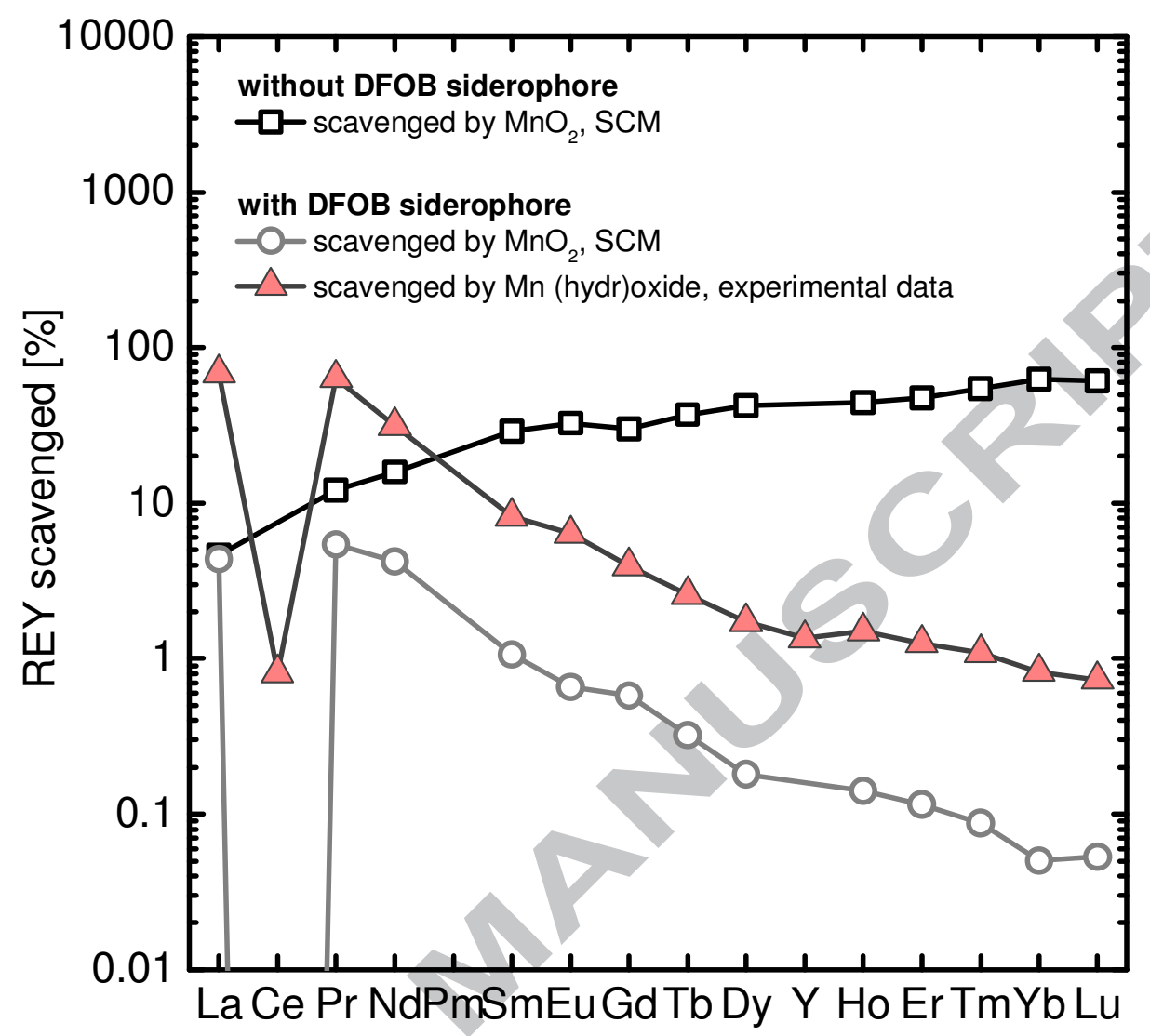

Fig. 6: Surface complexation model of REY(III) sorption onto $\mathrm{MnO}_{2}$ in absence and in presence of the biogenic ligand DFOB. Note that redox reactions were not included in the model without siderophores and therefore, $\mathrm{Ce}$ is omitted. Cerium(IV) was assumed in the SCM including siderophores. The experimental data is plotted for comparison. Note that although the extents in sorption differ from the modeled data, the pattern also shows LREY enrichment and HREY depletion and a distinct negative Ce anomaly. 
Table 1: Elemental composition of the artificial REY solution used in the sorption experiments of this study.

\begin{tabular}{|c|c|}
\hline \multicolumn{2}{|c|}{$\begin{array}{c}\text { Concentration in artificial } \\
\text { REY solution }\end{array}$} \\
\hline DFOB & $100 \mu \mathrm{mol} / \mathrm{L}$ \\
\hline $\mathrm{Mn}$ & $0.182 \mathrm{mmol} / \mathrm{L}$ \\
\hline $\mathrm{La}$ & $0.019 \mu \mathrm{mol} / \mathrm{L}$ \\
$\mathrm{Ce}$ & $0.074 \mu \mathrm{mol} / \mathrm{L}$ \\
$\mathrm{Pr}$ & $0.0186 \mu \mathrm{mol} / \mathrm{L}$ \\
$\mathrm{Nd}$ & $0.0686 \mu \mathrm{mol} / \mathrm{L}$ \\
$\mathrm{Sm}$ & $0.0170 \mu \mathrm{mol} / \mathrm{L}$ \\
$\mathrm{Eu}$ & $0.0035 \mu \mathrm{mol} / \mathrm{L}$ \\
$\mathrm{Gd}$ & $0.0163 \mu \mathrm{mol} / \mathrm{L}$ \\
$\mathrm{Tb}$ & $0.0032 \mu \mathrm{mol} / \mathrm{L}$ \\
$\mathrm{Dy}$ & $0.0168 \mu \mathrm{mol} / \mathrm{L}$ \\
$\mathrm{Y}$ & $0.1316 \mu \mathrm{mol} / \mathrm{L}$ \\
$\mathrm{Ho}$ & $0.00303 \mu \mathrm{mol} / \mathrm{L}$ \\
\hline $\mathrm{Er}$ & $0.0153 \mu \mathrm{mol} / \mathrm{L}$ \\
$\mathrm{Tm}$ & $0.003 \mu \mathrm{mol} / \mathrm{L}$ \\
$\mathrm{Yb}$ & $0.015 \mu \mathrm{mol} / \mathrm{L}$ \\
$\mathrm{Lu}$ & $0.00291 \mu \mathrm{mol} / \mathrm{L}$ \\
\hline $\mathrm{REY}$ & $0.407 \mu \mathrm{mol} / \mathrm{L}$ \\
\hline
\end{tabular}

